Article

\title{
The Effect of European Integration on Swiss Energy Policy and Governance
}

\author{
Paul Adrianus van Baal * and Matthias Finger \\ Collège du Management, École Polytechnique Fédérale de Lausanne, 1015 Lausanne, Switzerland; \\ E-Mails: paul.vanbaal@epfl.ch (P.A.v.B.), matthias.finger@epfl.ch (M.F.) \\ * Corresponding author
}

Submitted: 12 October 2018 | Accepted: 6 December 2018 | Published: 28 March 2019

\begin{abstract}
The unique "Swiss way" of association with the European Union (EU) has received increasing attention in light of recent events such as Brexit as it is based on sectoral agreements without an overarching institutional framework. As such, Europeanization of Swiss domestic policy does not follow a straightforward process. We examine the external governance processes that drive the Europeanization of Swiss energy policy. Switzerland and the EU are highly interdependent in energy due to Switzerland's geographical position but there is a relatively low level of policy alignment, as there is no formal EU-Swiss energy agreement nor has Switzerland autonomously implemented legislation equivalent to the EU energy acquis. The EU has fully liberalized the energy market and is focusing on consumer empowerment and decarbonization through the Clean Energy Package, whereas the Swiss energy sector remains only partially liberalized. Through a series of expert interviews with key stakeholders, we reconstruct the historical developments in Swiss energy policy, focusing on the relationship with, and the influence of the EU. We observe elements of each of the three ideal modes of governancemarkets, hierarchies, and networks. The relative importance of these modes of coordination in governing EU-Swiss energy relations has shifted considerably over time. Gradual harmonization of EU energy markets and certain key events have driven Swiss exclusion from EU network governance processes, leading to more hierarchy. We identify the strengths and weaknesses of each mode of governance for EU-Swiss energy relations in their historical setting and discuss the implications for energy policy in Switzerland in the context of the Clean Energy Package and EU external relations in general.
\end{abstract}

\section{Keywords}

energy policy; European Union; external governance; history; network governance; power; Switzerland

\section{Issue}

This article is part of the issue “EU Energy Policy: Towards a Clean Energy Transition?”, edited by Kacper Szulecki and Dag Harald Claes (University of Oslo, Norway).

(C) 2019 by the authors; licensee Cogitatio (Lisbon, Portugal). This article is licensed under a Creative Commons Attribution 4.0 International License (CC BY).

\section{Introduction}

The European Union (EU) associates with third countries in a variety of manners (Lavenex, Lemkuhl, \& Wichmann, 2009). The unique "Swiss way" of association has received increasing attention in the context of Brexit because Switzerland has no institutional framework agreement with the EU (Tobler, 2016). The EU-Swiss relationship is defined by sectoral agreements. Additionally, Switzerland has significantly aligned its domestic legislation with the EU in certain sectors without a formal agreement. There have been various quantitative stud- ies on the influence of EU policy on Swiss policy (Bartle, 2006; Gava \& Varone, 2014; Jenni, 2015). However, few analyze the governance processes that drive such adaptation. Identifying these processes is important because the absence of an institutional agreement between the EU and Switzerland implies a lack of standard procedures of association and could provide insight into future relations between the EU and other countries.

The case of electricity is particularly pertinent as the reliable operation of an electricity system requires the continuous cooperation of all parties involved. However, there is no formal EU-Swiss agreement on electric- 
ity. European energy affairs have traditionally been coordinated through various private and public networks (Jegen, 2009), yet, Switzerland's position in these networks has significantly deteriorated the last few decades, up to the point of exclusion in certain instances (Jenni, 2015). At the same time, Switzerland has committed to an ambitious energy transition focusing on the gradual phasing-out of nuclear energy, the most important source of electricity besides hydropower, which will likely increase its future dependence on the EU electricity system (Demiray et al., 2018; ElCom, 2018; Verhoog, van Baal, \& Finger, 2018).

Research on policy diffusion tells us that uncoordinated, unilateral adoption of EU-compatible policies in Switzerland can result from either competitive or coercive pressure, or through learning and emulation (Börzel \& Risse, 2011; Elkins \& Simmons, 2005; Simmons, Dobbin, \& Garret, 2006). The EU external governance literature started from the observation that the EU sphere of influence extends beyond its Member States (Friis \& Murphy, 1999) and has proven successful in explaining Europeanization processes (Lavenex, 2004; Mugyenzi, 2015; Schimmelfennig \& Sedelmeier, 2004). Both policy diffusion and external governance use 'conditionality' as a key mechanism driving policy proliferation in third countries. However, unlike policy diffusion, external governance theory is not limited to the implementation of policies but includes other forms of coordination as well, often studying these in light of the traditional 'modes' of governance-markets, hierarchy, and networks (see, e.g., Knill \& Tosun, 2009). Joint operation of the European power system requires continuous coordination between all countries involved, and external governance theory allows us to analyze all the governance processes involved. We use the external governance theoretical framework which was originally defined by Lavenex and Schimmelfennig (2009) to analyze the processes that drive the Europeanization of Swiss energy policy. The framework was developed specifically in a European context and offers several explanatory hypotheses regarding power relations, domestic structures, and EU institutions. As EU external governance modes are strongly path- and sector-dependent (Lavenex, Lemkuhl, et al., 2009), we have to look at how the current situation has developed to discuss the future implications for European integration.

We, therefore, reconstruct the history of EU-Swiss energy governance by utilizing public reports, press releases and official government publications, alongside thirteen interviews with key stakeholders. All of the stakeholders interviewed were directly involved with EU-Swiss (energy) affairs at a certain point in the history. We interviewed seven high-ranking public administration officials, two diplomats, and four business leaders. The stakeholder selection was made by mapping from the documentary sources and a snowball approach during the interview process. We took efforts to include critical voices and to balance European and Swiss perspectives.
Although the interviews were a primary source of information, we triangulated the information obtained with official documents and research reports for accuracy and reliability. Interviews are cited in-text as $\mathrm{CH}$ \# or EU\# and refer to a specific Swiss or EU interviewee, respectively. Anonymity was promised to all participants due to the current political sensitivity of EU-Swiss relations.

Section 2 explains the modes of external governance and relevant hypotheses in further detail. Section 3 and 4 describe the key elements of European and Swiss energy history, respectively. Special attention is given to those developments which have been relevant in the shaping of EU-Swiss relationship. Section 5 provides a discussion of these developments using the external governance framework. The last section summarizes our results and provides a perspective on the future of EU-Swiss energy relations.

\section{Modes of External Governance}

Williamson (1975) defined markets and hierarchies as distinct 'modes of governance', based on dispersed competition and hierarchical control, respectively. Later researchers pointed to networks as an additional mode of governance, based on reciprocal patterns of communication and exchange, contrasting and competing with markets and hierarchies (Jones, Hesterly, \& Borgatti, 1997; Powell, 1990). Although this governance approach was traditionally applied to internal governance, Lavenex (2004, p. 682) argued that the governance approach is particularly useful for studying EU external relations because of its emphasis on hierarchical and horizontal, formal and informal forms of policymaking. EU external governance has been defined as "institutionalized forms of coordinated action that aim at the production of collectively binding agreements...beyond the borders of the EU and its formal, legal authority" (Lavenex \& Schimmelfennig, 2009, p. 795). Using this definition, Lavenex and Schimmelfennig (2009) further defined the three ideal modes of governance in the context of EU external relations.

They firstly define hierarchical governance as a formalized, asymmetrical relationship based on the principle of domination and subordination, enforced through legally binding, non-negotiable legislation. They argue that the traditional form of hierarchy is never strictly present in an EU external governance context, as third countries retain formal sovereignty. Nonetheless, certain parts of EU external governance come close to this mode of governance, such as the European Economic Area (EEA) overarching framework agreement. They point to the existence of precise rules, formal procedures, monitoring, and sanctioning as indicators of hierarchy.

Secondly, Lavenex and Schimmelfennig (2009) define network governance as institutionalized, ongoing coordination, both formal and informal. Actors are formally equal, even if power imbalances exist, as no party is able to formally bind the other party without their con- 
sent. The presence of central institutions is a strong indicator of EU network governance, but network governance can also exist without a central institution (Provan $\&$ Kenis, 2008).

Thirdly, they define market governance as the outcome of competition between formally autonomous actors. In the context of EU external relations, this can be best seen by the competitive pressure of the Single Market. Competitive forces can drive an approximation of EU legislation or the adoption of EU standards in third countries, even without a formal requirement. This conceptualization of market governance invokes similar principles as described in the policy diffusion literature (see, e.g., Simmons et al., 2006), as the outcomes are the result of unilateral decisions of third countries in order to gain or avoid material consequences.

Lavenex and Schimmelfennig (2009) offer several hypotheses as to why certain governance forms become dominant. Observing that the mode of governance varies with structures of power relations and levels of interdependence, they hypothesize that an asymmetrical, high interdependence tends to favour hierarchical governance, whereas symmetrical, strong interdependence is most conducive to market governance. Network governance arises in situations with medium interdependence. In our analysis, we will examine whether these hypotheses hold in the case of EU-Swiss bilateralism in the area of energy. Table 1 summarizes the three modes of governance.

\section{European Energy History}

The history of European energy policy has been described by many authors (e.g., Hancher, 1997; Jevnaker, 2015; Meeus, Purchala, \& Belmans, 2005; Vasconcelos, 2005). This section will not provide a detailed account of EU energy policy development but rather highlight the most relevant aspects of the relationship with Switzerland. Figure 1 shows an overview of the most pertinent events and legislation.

\subsection{Transit Directives and First Energy Package}

The EU took the first step towards the internal energy market (IEM) by passing the Directives on the Transit of Electricity and Gas in 1990 and 1991, respectively (Nylander, 2001). These "Transit Directives" asked Member States to facilitate cross-border trade, without, however, specifying how. Further legislation was necessary to integrate the energy markets. In 1996, the first Electricity Directive was adopted; the first Gas Directive followed in 1998. This first "Energy Package" mandated legal unbundling, a transmission system operator, and the gradual opening of markets to competition (Meeus et al., 2005). Notably absent was a compensation mechanism for cross-border trading, which was to be settled bilaterally.

Aware of the regulatory gaps created by the first Energy Package, the European Commission (EC) convened the first Florence Forum in 1998 (Vasconcelos, 2005,

Table 1. Structural modes of EU external governance. Adapted from Lavenex and Schimmelfennig (2009).

\begin{tabular}{lllll}
\hline & Actor constellation & Institutionalization & Mechanism of rule expansion & Interdependence \\
\hline Hierarchy & $\begin{array}{l}\text { Vertical: domination } \\
\text { and subordination }\end{array}$ & Tight, formal & Harmonization & High, asymmetrical \\
\hline Network & Horizontal: formal & Medium-tight, both & Coordination, negotiation & Medium, symmetrical \\
& equality of partners & formal and informal & & or asymmetrical \\
\hline Market & Horizontal: formal & Loose, informal & Competition, market & High, symmetrical \\
& equality of partners & & pressure & \\
\hline
\end{tabular}

Note: the last column assumes the mode of governance is primarily determined by power relations.

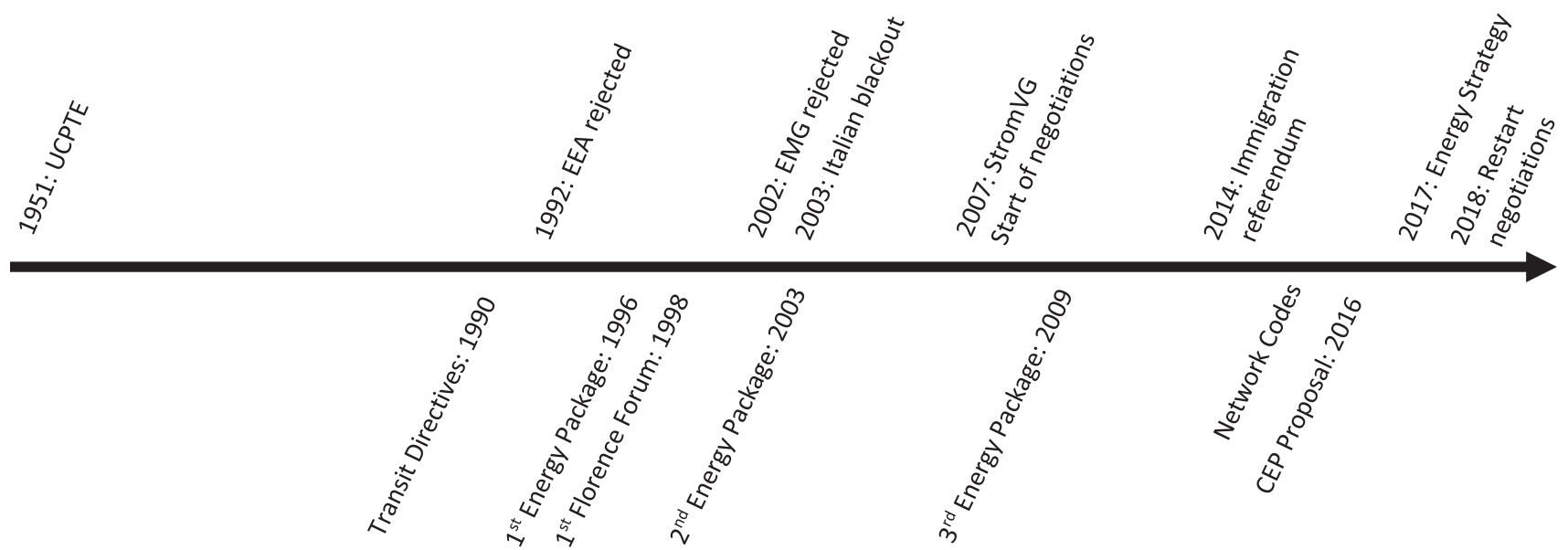

Figure 1. Timeline of relevant energy history of the EU (below) and Switzerland (above). 
p. 90), which brought together all relevant stakeholders to devise regulatory solutions through consensus building. New organizations were created to facilitate this process. Examples include the Council of European Energy Regulators (CEER) and the Association of European Transmission System Operators (ETSO). Their first task was to define a mechanism for cross-border trade. In 2000, a solution was developed and presented to the EC: crossborder trades would be settled through inter-TSO compensation (ITC), considering only physical flows and compensating transit countries such as Switzerland. However, adoption of this solution was delayed until 2003 due to fierce opposition mainly by the German government (Vasconcelos, 2005, p. 91).

\subsection{Second Energy Package}

Unsatisfied with the pace of liberalization and the remaining regulatory gaps (Jevnaker, 2015, p. 934), the EU adopted the second Energy Package in 2003. The legislative package mandated full market opening for all customers across the EU, stronger network access regulation, as well as the establishment of an independent regulator. It also created the European Regulators Group for Electricity and Gas (ERGEG), which was largely equivalent to the CEER but included the EC as an observing, nonvoting member (Coen \& Thatcher, 2008).

\subsection{Third Energy Package and Network Codes}

The newly established ERGEG had almost no formal power (Coen \& Thatcher, 2008) and adoption of the agreed regulatory solutions remained voluntary, which the EC considered inadequate (Jevnaker, 2015, p. 934). The solutions it provided were unclear and significant regulatory gaps remained across the IEM, especially regarding cross-border mechanisms. A third Energy Package aimed to solve these problems in 2009 through stronger EU-level governance and centralized cooperation (Jevnaker, 2015, p. 935). The Agency for the Cooperation of Energy Regulators (ACER) was created to succeed the ERGEG and the European Network of Transmission System Operators for Electricity (ENTSO-E) to succeed the ETSO and the Union for the Coordination of Transmission of Electricity (UCTE). These organizations institutionalized the informal power held by their predecessors. A new legislative process was started between ENTSO-E and ACER to develop the Network Codes (NCs)-binding standards on operation, connection and market conditions (Jevnaker, 2015, p. 928).

\subsection{Clean Energy Package}

The three Energy Packages had mostly focused on liberalization, integration, and security of supply. Climate and sustainability concerns were addressed by separate legislative packages. Proposed by the EC in November
2016, the Clean Energy Package (CEP) harmonizes climate and sustainability with the rest of EU energy policy. Besides updating the targets for the $\mathbf{2 0 3 0}$ horizon, the CEP legally defines new types of actors such as aggregators and local energy communities, expands the mandate of ACER, proposes an EU distribution system operator (DSO) entity, and expands the scope of the NCs (Meeus \& Nouicer, 2018).

\section{Swiss Energy History}

\subsection{Before 1990}

Switzerland was a main driver of European integration in the electricity sector as a founding member of the Union for the Coordination of Production and Transmission of Electricity (UCPTE) ${ }^{1}$. In 1958, the "Star of Laufenburg" substation was commissioned in the Canton of Aargau, connecting the electricity grids of Switzerland, France, and Germany for the first time. The UCPTE grid grew rapidly and by 1996 it crossed 19 European countries from Poland to Portugal, with the Laufenburg control centre still at its core (UCTE, 2009). The Swiss companies in the UCPTE were influential and were not restrained by the Swiss national authorities. Although national governments sometimes sent delegates to UCPTE meetings $(\mathrm{CH} 1)$, they held no formal power within the organization.

\subsection{0 to 2003}

In 1990, the Swiss public voted overwhelmingly in favour of giving the national government a constitutional energy mandate, which had previously been a mostly cantonal affair. In this period, the Swiss economy was stagnating, and following a referendum rejecting EEA membership in 1992, the Swiss government was exploring new ways to stimulate the economy. It was clear from the European side that the future of the electricity sector was going to be liberalized, unbundled, and competitive. Notable publications from de Pury (1995) and Cattin (1995) garnered significant media and political attention by highlighting the economic benefits of liberalization in Switzerland ( $\mathrm{CH} 1)$. A liberalization law, called the Electricity Market Law (EMG), was being drafted based on the recommendations of the Cattin report (Jegen, 2009). Although economic benefits were a main driver for the EMG, it was developed in line with the first Energy Package to ensure EU-compatibility and maintain market access (Jegen \& Wüstenhagen, 2001).

When the Florence Forum convened for the first time in 1998, the participating stakeholder organizations were not official EU institutions, and therefore membership was not strictly reserved to EU Member States. Thus, Swiss delegates were able to participate, unlike in the formal EU legislative process. Switzerland had less influence in the Florence Forum than it did in the UCPTE, but was able to participate and represent its interests. For in-

\footnotetext{
${ }^{1}$ The UCPTE changed its name to UCTE in 1999, dropping the " $\mathrm{P}$ " for production (UCTE, 2009).
} 
stance, the ITC solution proposed by the Florence Forum was co-developed and strongly advocated for by Swiss representatives as it favoured transit countries ( $\mathrm{CH} 6)$. Because there was no formal TSO or regulator in Switzerland, the electricity companies and the government sent delegates to represent these roles. Their European counterparts mostly accepted this, as long as they did not push their conflicting interests too strongly (CH6). It was the same for several EU Member States-not all of them had a regulator or had fully unbundled their companies. The credibility of Swiss actors in the Florence process was based on skilled diplomacy and on the "promise" that EUcompatible domestic legislation was in development, integration would proceed, and that their presence in Florence was therefore needed $(\mathrm{CH} 6)$.

The seven Swiss electricity companies that owned the high-voltage transmission grid set up ETRANS in 1999, an organization taking on the role of national grid operator. Creating ETRANS allowed the companies to retain ownership of their assets, as ETRANS merely coordinated their work centrally. The companies had openly been against the creation of a national grid company, afraid of losing ownership of their valuable grid assets (Bartle, 2006).

The EMG was rejected by referendum in 2002 (Jegen, 2009, p. 584). While the opposition did not appeal to an anti-European sentiment, the rejection could still be seen as a Eurosceptic outcome as the EMG was meant to streamline Swiss domestic policy with the EU. Regardless, the rejection did not elicit a strong reaction from the EU ( $\mathrm{CH} 1)$. Switzerland was still seen as a reliable country. The first Energy Package was a sort of "menu" approach where each Member State had a significant choice on how to direct their internal affairs (Hancher, 1997, p. 101). Hence, regulatory gaps were commonplace within internal EU borders and Switzerland, as an isolated case, did not raise too many concerns at that point. Additionally, technical compatibility, including regarding security measures, was assumed to be ensured through the UCTE.

\subsection{3 to 2014}

An Italian blackout originating on the Swiss border in 2003 changed the political landscape. The blackout had an immense effect: 56 million people were left without electricity for up to 19 hours, with economic damage estimated at about $€ 1.2$ billion (Walker, Cox, Loughhead, \& Roberts, 2014, p. 17). Switzerland was heavily criticized for not responding to the warning signals in a timely manner, as well as for not having a properly unbundled TSO (CH6; EU3). However, an official investigation showed that Switzerland had not broken UCTE rules and could thus not be held accountable for damages (UCTE, 2004). Regardless, it became clear that the UCTE rules were not strict enough to guarantee reliability, and that reliability depended on Swiss participation.

In April 2004, the Swiss companies voluntarily agreed to merge the seven transmission grids into a single con- trol area under control of Swissgrid, a Swiss TSO (d'Arcy \& Finger, 2014). This was not only in response to the European criticism but also in anticipation of a new domestic liberalization law which was sure to include a requirement for a Swiss TSO. By forming Swissgrid on their own terms, they could determine their own rules. Rather than owning the transmission grid directly, the companies took ownership of Swissgrid-it thus remains an imperfectly unbundled grid operator (d'Arcy \& Finger, 2014).

Even though the first liberalization law was rejected in 2002, the Federal Tribunal ruled in 2003 that the cartel law de facto necessitated liberalization (Bellanger \& Cavaleri Rudaz, 2006, p. 197). This allowed the government to propose a new liberalization law-the Electricity Supply Act (StromVG) - which passed in 2007 (Jegen, 2009 , p. 584). It called for the opening of the market in two steps, the creation of a national regulatory authority (EICom), and a national grid operator (Swissgrid). The electricity market was opened to all consumers with an annual consumption higher than 100 MWh in 2009 (Federal Council [FC], 2013). There was no referendum for the StromVG, primarily because the second liberalization step would be subject to a possible referendum.

After the blackout, calls for stricter coordination with Switzerland intensified on both sides ( $\mathrm{CH} 6$; $\mathrm{CH} 7$; EU1; EU2). Formal negotiations for a bilateral agreement on electricity started in 2007 (EC, 2007). The negotiations, although slow, were happening in good faith as the recent Swiss developments had consistently been EU-compatible. Pragmatism directed this indirect Europeanization: the changes not only aided in the overall security of supply and economic efficiency through enhanced EU-compatibility, but it also created goodwill by preparing for the implementation of the electricity agreement under negotiation.

Regardless of these domestic developments and the ongoing negotiations, Switzerland was slowly becoming less influential in European energy affairs. The second and third Energy Packages and subsequent creation of ERGEG and ACER in 2003 and 2009, respectively, institutionalized the network governance approach started by the EC with the Florence Forum after the first Energy Package. These organizations were now official EU organizations and therefore less open to delegates of nonMember States. This also held true for the programs that they launched, such as the Regional Initiatives, for which Switzerland was only an observer country (Jegen, 2009, p. 591). Nonetheless, when ENTSOE was created, Swissgrid was allowed to become a member as it had traditionally been a member of the UCTE which ENTSO-E succeeded. Through ENTSO-E, Swissgrid participated in the development of the NCs.

\subsection{4 to Present}

In 2014, eleven years after the Italian blackout and following seven years of formal bilateral negotiations, the end of the negotiations was in sight, with a verbal con- 
sensus having been achieved regarding many of the issues on the table ( $\mathrm{CH} 5)$. However, all negotiations were halted in 2014 when the Swiss population voted to limit immigration from all EU countries (Jenni, 2016, p. 284). This was in direct opposition to the Agreement on the Free Movement of People (AFMP) signed a decade earlier. The EC put all bilateral negotiations, including those on the electricity agreement, on hold pending on how the government decided to implement the referendum results (EC, 2014). Most EU-Swiss agreements contain guillotine clauses, meaning they can all be terminated if one party terminates a single agreement.

The political relationship with Switzerland became strained (CH5; EU3). When the first NCs came into force, they had an ultimatum for Switzerland: until a bilateral electricity agreement was signed, Switzerland would be excluded from participating in the intraday, day-ahead, and balancing market coupling mechanisms of the $\mathrm{EU}^{2}$. Besides a loss of market opportunities, this exclusion caused an increase in unscheduled loop flows and a subsequent need for re-dispatching in Switzerland (Swissgrid, 2018).

In 2016, Switzerland implemented an AFMPcompatible version of the immigration bill in order to appease the EU (FC, 2016). The open dossiers could be picked up again (EC, 2016). However, the relationship had changed drastically (CH5). Switzerland had become acutely aware of its dependency on the EU, and the EU was not sure how to deal with Switzerland. It was not in their interest to break all ties with Switzerland, however, they wanted to make clear that the agreements were an "all or nothing" package. The EU was dealing with several crises-a dragging economic crisis, the refugee crisis, and Brexit. Uncertainty in the relationship with Switzerland was far from desirable and the EU could not set a soft precedent in light of Brexit (Brunsden \& Atkins, 2018). A sentiment of distrust had also grown in Brussels regarding Swiss politicians, as their promises and any agreements were limited by federal competencies and the possibility for referenda ( $\mathrm{CH} 5)$. Even though it was not formally ended at the time, the EU had already signalled back in 2008 that the unique "Swiss way" of association based on bilateral agreements was reaching its limits (Council of the European Union, 2014). Preliminary negotiations on an institutional framework started in 2011 (FC, 2011). However, after the 2014 referendum, all open dossiers became conditional on the institutional framework negotiations, including the electricity agreement ( $\mathrm{CH} 5)$.

Prior to 1990, when the EU started legislating, Switzerland was central and influential in European energy affairs. This stands in stark contrast to the situation in 2018, when it had become excluded from influential organizations and market mechanisms. Gradual EU institutionalization and key events such as the 2003 blackout and 2014 referendum were the main contributors. This deterioration of the Swiss position has gone hand in hand with a shift in the power balance. Whereas in previous decades the EU wanted an agreement with Switzerland because of its strong interconnection and valuable hydropower resources, it is now Switzerland that needs an agreement with the EU. Deteriorating market access could have real consequences for Swiss security of supply, while EU countries are gradually increasing their interconnection (EC, 2017), making Switzerland less essential as a transit country.

Contemporary Swiss energy policy is focused around the Energy Strategy 2050 (ES50). Passed by referendum in 2017, the legislative package embodies the Swiss sustainability transition: gradually phasing-out nuclear energy while supporting renewables and energy efficiency (FC, 2017). This nuclear phase-out is likely to increase Swiss reliance on electricity imports, both seasonal and annual, further exacerbating this shift in power (Demiray et al., 2018; ElCom, 2018; Verhoog, van Baal, \& Finger, 2017). In comparison to the CEP, which is a broad legislative package focusing on consumer empowerment, security of supply, energy market design, as well as climate and sustainability goals, the ES50 is more limited as it focuses solely on the latter. A revision of the StromVG, for which the parliamentary process started in 2018, is scheduled to address those other issues (FC, 2018).

\section{Discussion}

\subsection{Networks}

Network governance can be seen early on in European energy affairs. The creation of the UCPTE, a network administrative organization, by the electricity companies, is a clear sign of network governance (Provan \& Kenis, 2008). This organization was coordinating the European power grid long before the EU became involved. The UCPTE's rapid growth and the duration of its existence is a clear sign of the success of this type of coordination.

Network governance continued to be the preferred method of governance for the EU when it began legislating the energy markets. The consecutive energy packages gradually institutionalized the network governance mechanisms. Jegen (2009) shows that this institutionalization has progressively made it harder for Switzerland to participate. However, we observe an overall trend of increasing hierarchy as well, with EU legislation increasingly taking over network functions.

The Transit Directives, and to a certain degree the first Energy Package, contained few binding rules and left the Member States ample choice to coordinate and implement their own procedures and standards. The UCPTE was in the ideal position to take a leading position but failed to do so to a sufficient extent. The creation of the Florence Forum by the EC was meant to find regulatory solutions through network governance. The voluntary rule-creation in Florence was still open to representatives of invited third countries. Swiss companies, repre-

\footnotetext{
${ }^{2}$ See art. 1(6) of the Electricity Balancing Guideline and art. 1(4) of the Guideline on Capacity Allocation and Congestion Management.
} 
sented through ETRANS, were successfully able to represent their interests. However, the participants in the Florence Forum failed to reach consensus on the ITC, and the EU subsequently felt compelled to enforce the measure in the second Energy Package.

The 2003 blackout further showed that weak forms of coordination were not sufficient to ensure reliability in the increasingly complex grid. The EU intervened with the third Energy Package by creating a new organization, ENTSO-E, to take over the functions of the UCTE and ETSO. If the companies in those organizations had committed to binding technical rules through the UCTE, perhaps this would not have been necessary. The UCTE was a loose form of collaboration relying more on mutual trust than binding rules. Even though ENTSO-E is still a network organization, it is an EU agency mandated to create legally binding rules and procedures, introducing more hierarchy into the network. The first NCsdeveloped by ENTSO-E and ACER-excluded Switzerland from participation in several market mechanisms.

The formation of Swissgrid, in the wake of the Italian blackout, was a clear signal of network governance as well. Although there was no clear hierarchy enforcing the creation of a TSO, the criticism endured from other network participants - at the Florence Forum and through the UCTE-spurred this approximation of EU energy policy, even in the absence of domestic legislation. Much of the work that Swissgrid has done in the subsequent years to coordinate technical affairs through ENTSO-E can be attributed to network governance as well.

Lavenex and Schimmelfennig (2009) postulate that network governance is most favoured in situations of medium interdependence, both in asymmetric as well as symmetric power relations, which seems to be consistent with our observations. Interdependence of the European electricity markets has grown continuously, both physically and economically, and as a result, pure network solutions were no longer deemed sufficient or optimal, leading the EU to introduce governance processes that were more hierarchical in nature.

\subsection{Markets}

Jegen (2009) argues that Swiss companies' successful participation in UCTE and ETSO is a form of market governance which at least partially compensates for the decline in their influence over the increasing institutionalization of EU energy policy. We argue this is not a form of market governance, driven by dispersed competition, but rather a form of network governance as it results from ongoing multilateral coordination through a central organization. The Swiss network participants are predominantly market actors but that does not imply competitive pressure is de facto the driving mode of governance.

Markets have rarely been the dominant mode of governance in EU-Swiss energy relations. Throughout most of the 20th century, energy companies remained verti- cally integrated companies. Since their monopolies were often legally protected, there was no competitive pressure that could incite any approach of EU-Swiss legislation. Rather, network governance coordinated the relations between companies through the UCTE as soon as trade became possible, due to the complexity of the physical infrastructure.

Nonetheless, when EU Member States started opening their electricity markets and breaking monopolies, competitive pressure arrived. One of the strongest rationales for the first liberalization law in Switzerland was EU compatibility to ensure market access (Jegen \& Wüstenhagen, 2001). Even though it was ultimately rejected, and liberalization did not arrive in Switzerland at that time, the Swiss companies felt compelled to change their business model. The formation of ETRANS is a clear example. The Laufenburg control centre had historically been operated by EGL who therefore had longstanding relationships with foreign electricity companies. The other Swiss companies were afraid that these business relationships would become a significant competitive advantage for EGL once they were able to start trading across Europe ( $\mathrm{CH} 6)$. The Swiss companies were therefore in favour of creating ETRANS, as the control centre would come under the control of all seven companies. This decision was not negotiated with any EU authority or through any network. Market pressure spurred this form of adaptation to EU energy policy in the absence of any hierarchy or network.

Other examples of adaptation to EU energy policy can be attributed, at least partly, to market pressure. Examples include the EU-compatible provisions of the StromVG and the introduction of a power exchange in Switzerland. This does not preclude domestic affairs being the main driver of these developments but merely points to the presence of economic pressure as a contributing factor. A common factor is asymmetry, as it has consistently been Switzerland which has followed EU developments, contradicting the hypothesis of Lavenex and Schimmelfennig (2009) that market governance stems from symmetrical power relations.

\subsection{Hierarchies}

Negotiated bilateralism was established as the mode of EU-Swiss coordination after Switzerland rejected EEA membership in 1992. Lavenex and Schimmelfennig (2009) would argue that this is a form of network governance, as both actors retain formal sovereignty and rule expansion is based on mutual consent. However, we argue that Swiss bilateralism has evolved into a type of hierarchical governance. When the Swiss population voted to restrict immigration in 2014, the guillotine clauses in the bilateral agreements acted as a way to enforce compliance. Formally speaking, Switzerland could have implemented immigration quotas for EU nationals as the referendum demanded, but this would have broken all bilateral agreements with the EU and therefore Switzer- 
land refrained. The EU relationship has become an "all or nothing" package akin to the EEA or even EU membership itself, as Brexit has demonstrated. The asymmetrical power balance between Switzerland and the EU has developed into a form of hierarchical governance in those areas where bilateral agreements have been signed.

The negotiations for such an agreement in electricity have been ongoing since 2007. If successful, the scope of this hierarchy will be extended to electricity. Even though EU legislation has no formal power over Switzerland, recent EU energy legislation tries to pressure Switzerland to comply regardless - a sign that hierarchy is being established. The NCs exert strong market pressure by explicitly excluding Switzerland from market coupling on the intraday, day-ahead, and balancing markets until an agreement is signed. Market pressure has been a strong motivation for Switzerland to pass EU-compatible legislation in the past, as described in the previous section. The NCs also contain technical standards which for Switzerland are practically impossible not to follow due to its physical integration into the European power grid. This trend of increasing hierarchy, also briefly hinted at in section 5.1, is consistent with the hypothesis of Lavenex and Schimmelfennig (2009) that high, asymmetrical interdependence tends to favour hierarchical external governance.

\section{Conclusion}

We examined Swiss-EU bilateralism in energy as a case for EU external governance. This section will summarize our main findings as well as provide a discussion on the implications for future EU-Swiss relations and EU external governance.

European energy affairs have historically been coordinated through network governance. EU modes of external governance are strongly path-dependent (Lavenex, Lemkuhl, et al., 2009), as can be seen in energy. Network governance remained the dominant mode of coordination when the EU started legislating. However, the trend towards hierarchy is clear in both EU internal and external governance. Other researchers have similarly pointed out that even though the EU institutionalized network governance, it has retained formal power and hierarchically enforces compliance (Coen \& Thatcher, 2008; Eberlein \& Grande, 2005). This trend has continued with the subsequent passing of new EU energy legislation. This steady march of institutionalization of the EU energy market has made the relationship with Switzerland increasingly asymmetric, and we observe a consequent marginalization of the role of Switzerland in European network governance, in which it had traditionally held a central role. Key events such as the 2003 Italian blackout and 2014 immigration referendum further contributed to these shifts in the mode of governance. These findings are consistent with the powerbased hypotheses of Lavenex and Schimmelfennig (2009) concerning hierarchy and networks as modes of external governance, favouring hierarchy when interdependence is higher and asymmetric. Nonetheless, only network governance provides an organizational opening for the inclusion of third countries in the policy process of the $\mathrm{EU}$, as hierarchy assumes an institutional relationshipwhich Switzerland formally does not have-and the implied absence of hierarchy in market governance precludes organizational inclusion.

The ongoing negotiations present an opportunity as well as a risk to Switzerland. The risk lies in deepening the hierarchical relationship that has emerged over the years, following the trend of hierarchy seen in internal EU affairs. If an agreement is signed on electricity, with or without an institutional framework agreement, it will likely contain an explicit or implicit guillotine clause linking it to the existing bilateral agreements, further developing the hierarchical relationship. However, the opportunity lies in the re-integration into the network governance mechanisms of the EU, in which it has historically been particularly capable in advocating its interests. The CEP expands the scope of the NCs, which are negotiated and drafted by the central institutions ENTSO-E and ACER. The CEP further proposes the creation of a DSO-entity that will also participate in the creation of the NCs (Meeus \& Nouicer, 2018). Participation and voting rights in ACER and the new DSO-entity would integrate Switzerland into these legislative processes. Such inclusion will only be possible through an agreement between the EU and Switzerland. The interdependence of the EU and Swiss energy sectors will mean the second generation of NCs will have a similarly strong impact on Switzerland as the first generation, regardless of whether or not an agreement is signed.

Exclusion has not only diminished Swiss influence on legislative processes but also its market access. Historically, market pressure was a strong driver for Switzerland to unilaterally adopt EU-compatible legislation. The increasingly asymmetrical power balance between the EU and Switzerland makes it hard for Switzerland to resist such pressure and it is therefore likely that this will impact the future relationship.

However, the CEP is not included in the negotiation mandate for the EU-Swiss electricity agreement. The negotiation mandate was originally based on the second Energy Package but was extended to include the third Energy Package in 2010 (FC, 2010), therefore it is possible the CEP is added at a later stage. Regardless, the second generation of NCs it proposes will be coordinated through the network agencies into which Switzerland could become a member. Thus, even if the agreement does not include the CEP, it would be able to participate in the legislative process.

It is unlikely that Switzerland will implement the CEP provisions without an agreement. Swiss and EU energy policy has increasingly diverged since the passage of the third Energy Package, and this trend will likely continue if no agreement is signed. The second generation of NCs might contain exclusion provisions, as has been 
the case with the first generation. The past rationale to autonomously adopt EU-compatible legislation was, for the most part, to ensure technical compatibility and market access. However, such incentives are not provided by the CEP. The way forward for EU-Swiss bilateralism thus remains politically uncertain. However, it is clear that the question of whether or not Switzerland will further diverge or integrate into the EU energy markets will depend on general EU-Swiss relations more than sectoral dynamics.

Although not the topic of this study, our findings have implications for the relations of other third countries with the EU. The harmonization and institutionalization of the internal market, one of the core missions of EU internal policy, has given the EU increasing leverage in its relations with neighbouring countries. Membership conditionality is no longer the strongest leverage over governance processes the EU has in its association with third countries. Membership in various network organizations, such as ACER or ENTSO-E in energy, and participation in pan-European policy initiatives such as electricity market coupling platforms, might be a stronger influencing factor than EU membership for countries without EU membership aspirations such as the UK or Switzerland. This increasingly asymmetric relationship means external governance processes will be more hierarchical and thus exceptions are less likely to be granted in future bilateral negotiations. The "Swiss way" of EU association was mostly negotiated in a time when the EU internal market was not as advanced as it is today and can be considered an artefact rather than a realistic option for other countries.

\section{Acknowledgments}

This research was funded by the SNFS (Swiss National Science Foundation) and aligns with the activities of SCCER CREST (Swiss Competence Center for Energy Research).

\section{Conflict of Interests}

The authors declare no conflict of interests.

\section{References}

Bartle, I. (2006). Europeans outside the EU: Telecommunications and electricity reform in Norway and Switzerland. Governance, 19(3), 407-436.

Bellanger, F., \& Cavaleri Rudaz, C. (2006). La réforme du service public de l'eau, du gaz, et de l'électricité [The reform of the public service of water, gas, and electricity]. In T. Tanquerel \& F. Bellanger (Eds.), Le service public (pp. 193-220). Geneva: Schulthess.

Börzel, T. A., \& Risse, T. (2011). From Europeanisation to diffusion: Introduction. West European Politics, 35(1), 1-19.

Brunsden, J., \& Atkins, R. (2018, January 19). EU's Swiss proposal could serve as Brexit blueprint. Financial Times. Retrieved from http://www.ft.com
Cattin, J. (1995). Öffnung des Elektrizitätsmarktes [Opening of the electricity market] (BEW-Schriftenreihe Nr. 54). Bern: Bundesamt für Energiewirtshaft.

Coen, D., \& Thatcher, M. (2008). Network governance and multi-level delegation: European networks of regulatory agencies. Journal of Public Policy, 28(1), 49-71.

Council of the European Union. (2014, May 6). Negotiating mandate for an EU-Switzerland institutional framework agreement [Press release]. Retrieved from https://www.consilium.europa.eu/ uedocs/cms_data/docs/pressdata/en/er/142503.pdf

d'Arcy, A., \& Finger, M. (2014). The challenges of imperfectly unbundled TSOs: Can corporate governance or regulatory action mitigate such imperfection? Competition and Regulation in Network Industries, 15(2), 117-137.

De Pury, D. (1995). Mut zum Aufbruch: eine wirtschaftspolitische Agenda für die Schweiz [The courage to depart: an economic policy agenda for Switzerland]. Zurich: Orell Füssli.

Demiray, T., Weigt, J., Beccuti, G., Schlecht, I., Savelsberg, J., \& Schillinger, M. (2018). Modellierung der System Adequacy in der Schweiz im Bereich Strom [Modelling system adequacy in Switzerland in the electricity sector]. Bern: Bundesamt für Energie.

Eberlein, B., \& Grande, E. (2005). Beyond delegation: Transnational regulatory regimes and the EU regulatory state. Journal of European Public Policy, 12(1), 89-112.

ElCom. (2018). System Adequacy 2025-Studie zur Versorgungssicherheit der Schweiz im Jahr 2025 [System adequacy 2025-Study on security of supply in Switzerland in the year 2025]. Bern: Eidgenössische Elektrizitätskommission ElCom.

Elkins, Z., \& Simmons, B. (2005). On waves, clusters, and diffusion: A conceptual framework. The Annals of the American Academy of Political and Social Science, 598(1), 33-51.

European Commission. (2007, November 8). Launching of negotiations between Switzerland and the EU for an agreement on electricity [Press release]. Retrieved from http://europa.eu/rapid/press-release_IP-071665_en.htm

European Commission. (2014, February 26). Developments following the Swiss referendum on 9th February-Statement by European Commissioner László Andor on behalf of European Commission to European Parliament plenary session [Press release]. Retrieved from http://europa.eu/rapid/pressrelease_STATEMENT-14-32_en.htm

European Commission. (2016, December 22). European Commission welcomes progress in relations between the European Union and Switzerland [Press release]. Retrieved from http://europa.eu/rapid/pressrelease_IP-16-4501_en.htm

European Commission. (2017, November 23). Communication on strengthening Europe's energy 
networks. Retrieved from https://ec.europa.eu/ energy/sites/ener/files/documents/communication_ on_infrastructure_17.pdf

Federal Council. (2010, September 17). Le Conseil fédéral confirme l'extension du mandat de négociation d'un accord sur l'énergie avec l'UE [The Federal Council confirms the extension of the negotiation mandate for an energy agreement with the EU; Press release]. Retrieved from https://www.admin.ch/gov/ $\mathrm{fr} /$ accueil/documentation/communiques.msg-id-351 80.html

Federal Council. (2011, February 8). Federal President Micheline Calmy-Rey in Brussels [Press release]. Retrieved from https://www.admin.ch/gov/ en/start/dokumentation/medienmitteilungen.msgid-37590.html

Federal Council. (2013, November 25). Le marché de l'électricité commence à jouer [The electricity market starts to play; Press release]. https://www.admin.ch/ gov/fr/accueil/documentation/communiques.msg-id51090.html

Federal Council. (2016, December 22). Schweiz informiert die EU über die Umsetzung des Zuwanderungsartikels [Switzerland informs the EU on the implementation of the immigration article; Press release]. Retrieved from https://www.admin.ch/gov/ de/start/dokumentation/medienmitteilungen.msgid-65099.html

Federal Council. (2017, November 2). Bundesrat setzt totalrevidiertes Energiegesetz per 2018 in Kraft [Federal Council enacts fully revised energy law in 2018; Press release]. Retrieved from https://www.admin. $\mathrm{ch} / \mathrm{gov} / \mathrm{de} / \mathrm{start} /$ dokumentation/medienmitteilungen. msg-id-68637.html

Federal Council. (2018, October 17). Bundesrat startet Vernehmlassung zur Revision des Stromversorgungsgesetzes [Federal Council opens the consultation on the revision of the electricity supply act; Press release]. Retrieved from https://www.admin.ch/gov/ $\mathrm{de} /$ start/dokumentation/medienmitteilungen.msgid-72549.html

Friis, L., \& Murphy, A. (1999). The European Union and Central and Eastern Europe: Governance and boundaries. Journal of Common Market Studies, 37(2), 11-32.

Gava, R., \& Varone, F. (2014). The EU's footprint in Swiss policy change: A quantitative assessment of primary and secondary legislation (1999-2012). Swiss Political Science Review, 20(2), 216-222.

Hancher, L. (1997). Slow and not so sure: Europe's long march to electricity market liberalization. The Electricity Journal, 10(9), 92-101.

Jegen, M. (2009). Swiss energy policy and the challenge of European governance. Swiss Political Science Review, 15(4), 577-602.

Jegen, M., \& Wüstenhagen, R. (2001). Modernise it, sustainabilise it! Swiss energy policy on the eve of electricity market liberalization. Energy Policy, 29(1), 45-54.
Jenni, S. (2015). Switzerland's regulatory European integration: Between tacit consensus and noisy dissensus. Swiss Political Science Review, 21(4), 508-537.

Jenni, S. (2016). Switzerland's differentiated European integration. London: Palgrave Macmillan.

Jevnaker, T. (2015). Pushing administrative EU integration: The path towards European network codes for electricity. Journal of European Public Policy, 22(7), 927-947.

Jones, C., Hesterly, W. S., \& Borgatti, S. P. (1997). A general theory of network governance: Exchange conditions and social mechanisms. Academy of Management Review, 22(4), 911-945.

Knill, C, \& Tosun, J. (2009). Hierarchy, networks, or markets: How does the EU shape environmental policy adoptions within and beyond its borders? Journal of European Public Policy, 16(6), 873-894.

Lavenex, S. (2004). EU external governance in 'wider Europe'. Journal of European Public Policy, 11(4), 680-700.

Lavenex, S., \& Schimmelfennig, F. (2009). EU rules beyond EU borders: Theorizing external governance in European politics. Journal of European Public Policy, 16(6), 791-812.

Lavenex, S., Lemkuhl, D., \& Wichmann, N. (2009). Modes of external governance: A cross-national and crosssectoral comparison. Journal of European Public Policy, 16(6), 813-833.

Meeus, L., \& Nouicer, A. (2018). The EU clean energy package. Florence: European University Institute.

Meeus, L., Purchala, K., \& Belmans, R. (2005). Development of the internal electricity market in Europe. The Electricity Journal, 18(6), 25-35.

Mugyenzi, J. (2015). EU external governance: Regionalizing multilevel networks of governance. Journal of European Integration, 37(3), 353-370.

Nylander, J. (2001). The construction of a market-A frame analysis of the liberalization of the electricity market in the European Union. European Societies, 3(3), 289-314.

Powell, W. W. (1990). Neither market nor hierarchy: Network forms of organization. In B. Staw \& L. L. Cummings (Eds.), Research in organizational behavior (pp. 295-338). Greenwich, CT: JAI Press.

Provan, K. G., \& Kenis, P. (2008). Modes of network governance: Structure, management, and effectiveness. Journal of Public Administration Research and Theory, 18(2), 229-252.

Schimmelfennig, F., \& Sedelmeier, U. (2004). Governance by conditionality: EU rule transfer to the candidate countries of Central and Eastern Europe. Journal of European Public Policy, 11(4), 661-679.

Simmons, B. A., Dobbin, F., \& Garrett, G. (2006). Introduction: The international diffusion of liberalism. International Organization, 60(4), 781-810.

Swissgrid. (2018, April 24). Swissgrid präsentiert robustes Ergebnis 2017 und stellt die Weichen für die Zukunft 
[Swissgrid presents robust results of 2017 and sets the course for the future; Press release]. Retrieved from https://www.swissgrid.ch/de/home/about-us/ newsroom/newsfeed/20180424-01.html

Tobler, C. (2016). One of many challenges after 'Brexit': The institutional framework of an alternative agreement-Lessons from Switzerland and elsewhere? Maastricht Journal of European and Comparative Law, 23(4), 575-594.

Union for the Coordination of Transmission of Electricity. (2004). Final report of the Investigation Committee on the 28 September 2003 blackout in Italy. Brussels: Secretariat of UCTE.

Union for the Coordination of Transmission of Electricity. (2009). UCPTE/UCTE: The 50 year success storyEvolution of a European interconnected grid. Brussels: Secretariat of UCTE.
Verhoog, R., van Baal, P., \& Finger, M. (2018). System dynamics simulation to explore the impact of low European electricity prices on Swiss generation capacity investments. In A. Dorsman, V. Ediger \& M. Karan (Eds.), Energy Economy, Finance and Geostrategy (pp. 31-61). Cham, Switzerland: Springer.

Vasconcelos, J. (2005). Towards the internal energy market, how to bridge a regulatory gap and build a regulatory framework. European Review of Energy Markets, 1(1), 23.

Walker, A., Cox, E., Loughhead, J., \& Roberts, J. (2014). Counting the cost: The economic and social costs of electricity shortfalls in the UK. London: Royal Academy of Engineering.

Williamson, O. E. (1975). Markets and hierarchies: Analysis and antitrust implications. New York, NY: Free Press.

\section{About the Authors}

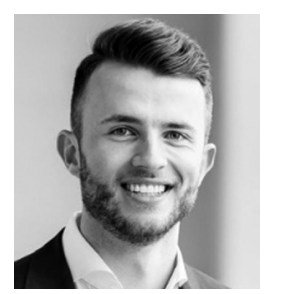

Paul Adrianus van Baal is a PhD candidate at the Swiss Post Chair in Management of Network Industries at the Swiss Federal Institute of Technology in Lausanne (EPFL). He combines his interests in sustainability and socio-technical transitions in his research, which focuses on electricity markets and policy analysis for the energy transition.

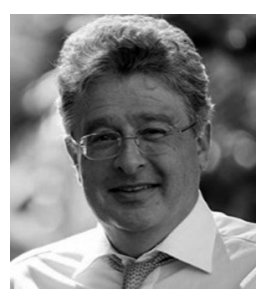

Matthias Finger is a Full Professor and holder of the Swiss Post Chair in Management of Network Industries at the Swiss Federal Institute of Technology in Lausanne (EPFL), editor-in-chief of the Journal on Competition and Regulation in Network Industries, Area Director for Transport at the Florence School of Regulation, and member of the Swiss Federal Electricity Regulatory Commission (ElCom). His main interest is in the de- and re-regulation of the network industries (postal services, telecommunications, electricity, railways, air transport, urban public transport, and water). 